УДК 342.9

DOI https://doi.org/10.51989/NUL.2021.4.31

\title{
ОСОБЛИВОСТІ ПРОВАДЖЕНЬ ЩОДО ЗМІНИ ЦІЛЬОВОГО ПРИЗНАЧЕННЯ ЗЕМЕЛЬНИХ ДІЛЯНОК
}

\author{
Залєвський Владислав Едуардович, \\ аспірант юридичного факультету \\ Харківського національного університету імені В.Н. Каразіна
}

Статтю присвячено дослідженню правової природи проваджень щодо зміни цільового призначення земельних ділянок. У процесі наукових досліджень у різних галузях права часто виникає необхідність визначити правову природу того чи іншого правового явища. Така необхідність зумовлена потребою в 3'ясуванні характерних ознак такого явища й на підставі їх аналізу віднесенні до існуючих класів правових явищ відповідної природи. Однак у процесі законотворчої діяльності часто з'являються такі нормативні конструкції, особливості яких або не дають можливості чітко визначити їх правову природу, або дають можливість віднести їх одразу до декількох різних класів досліджуваного явища. Прикладом такої нормативної конструкції є конструкція провадження зі зміни цільового призначення земельних ділянок, яка міститься в Земельному кодексі України. Отже, постає проблема визначення правової природи відповідного провадження. Проблемою сучасних досліджень процесуальних аспектів правового регулювання у сфері земельних відносин $\epsilon$ їх розгляд або з позицій виключно земельного, або з позицій виключно адміністративного права. Це призводить до однобічності й недостатньої об'єктивності висновків. У статті на підставі аналізу норм земельного законодавства й з урахуванням сучасних поглядів на класифікацію адміністративних проваджень у сфері земельних відносин показано, що провадженням щодо зміни цільового призначення земельних ділянок притаманний певний дуалізм їхньої правової природи в межах адміністративного типу проваджень. Залежно від форми власності зміна цільового призначення земельної ділянки може розглядатись або як провадження з надання адміністративних послуг, або як провадження з прийняття управлінського рішення в межах реалізації правомочностей управління об'єктами державної чи комунальної власності. Це залежить від загальної процесуальної мети провадження та характеристик суб'єктів відповідних процесуальних відносин. Використаний у статті підхід до визначення правової природи проваджень щодо зміни цільового призначення земельних ділянок може стати в нагоді для формування критеріїв класифікації адміністративних проваджень у сфері земельних відносин.

Ключові слова: адміністративне провадження, земельні відносини, цільове призначення земельних ділянок, адміністративні послуги.

\section{Zalievskyi Vladyslav. Features of proceedings on land usage change}

The article is devoted to the study of the legal nature of proceedings regarding land plots purpose change. In the process of scientific research in various fields of law there is often a need to determine the legal nature of one or another legal phenomenon. This need results from the necessity to clarify the characteristics of such a phenomenon and, on the basis of their analysis, refer to existing classes of legal phenomena of the appropriate nature. However, in the course of legislative activity, such normative constructions often appear, the features of which either do not make it possible to clearly and define their legal nature, or classify them into several different classes of the phenomenon under study. An example of such a normative construction is the one of proceedings to change the purpose of land, which is comprised in the Land Code of Ukraine. Hence the problem of determining the legal nature of the relevant proceedings arises. The problem of up-to-date research of legal regulation procedural aspects in the field of land relations is their consideration either from the standpoint of exclusively land law, or from the one of purely administrative law. This leads to one-sidedness and insufficient objectivity of the conclusions. Based on the matter of law analysis relating to land and taking into account relevant views on the administrative proceedings classification in the field of land tenure arrangements in the article, it is revealed that the proceedings to the land purpose change are characterized by a certain dualism of legal nature within administrative proceedings. 
Depending on the form of ownership, the land plot purpose change can be considered either as a procedure for administrative services provision, or as a procedure for making a management decision within the implementation of state or communal property objects. It depends on the general procedural purpose of the proceedings and the characteristics of the respective procedural relations subjects. The approach used in the article to determine the legal nature of proceedings to change the land purpose may be useful for the criteria formation in the classification of administrative proceedings in the field of land relations.

Key words: administrative proceedings, land tenure arrangements, land plots purpose, administrative services.

Постановка проблеми. У процесі наукових досліджень у різних галузях права часто виникає необхідність визначити правову природу того чи іншого правового явища. Така необхідність зумовлена потребою в з'ясуванні характерних ознак такого явища й на підставі їх аналізу віднесенні до існуючих класів правових явищ відповідної природи. Однак у процесі законотворчої діяльності часто з'являються такі нормативні конструкції, особливості яких або не дають можливості чітко визначити їх правову природу, або дають можливість віднести їх одразу до декількох різних класів досліджуваного явища. Прикладом такої нормативної конструкції $\epsilon$ конструкція провадження зі зміни цільового призначення земельних ділянок, яка міститься і Земельному кодексі України (далі - ЗКУ) [1]. Отже, постає проблема визначення правової природи відповідного провадження.

Метою статті $\epsilon$ визначення правової природи проваджень щодо зміни цільового призначення земельних ділянок.

Процесуальним аспектам земельних відносин приділялась досить серйозна увага таких дослідників, як Д.В. Ковальський та О.П. Світличний. Водночас перший розглядав відповідні процесуальні конструкції з позицій земельного права [2], а другий - з позицій адміністративного [3]. Значна кількість наукових праць присвячена адміністративним послугам у сфері земельних відносин, серед яких слід відзначити праці Д.В. Бусуйок, Н.М. Козаченко, Л.В. Мілімко й інших. Однак провадження зі зміни цільового призначення земельних ділянок значною мірою залишились поза увагою відомих дослідників, тому цю прогалину необхідно заповнити.

Виклад основного матеріалу. Стосовно галузевої належності норм, якими регламентується провадження зі зміни цільового призначення земельних ділянок, то тут суттєвих проблем не виникає. Відповідно до частини другої статті 20 ЗКУ зміна цільового призначення земельних ділянок державної або комунальної власності провадиться Верховною Радою Автономної Республіки Крим, Радою міністрів Автономної Республіки Крим, органами виконавчої влади або органами місцевого самоврядування, які приймають рішення про затвердження проєктів землеустрою щодо відведення земельних ділянок і передачу цих ділянок у власність або надання в користування відповідно до повноважень, визначених статтею 122 цього Кодексу. А відповідно до частини третьої цієї ж статті зміна цільового призначення земельних ділянок, що не належать до державної чи комунальної власності, здійснюється сільською, селищною, міською радою.

Зміст зазначених норм свідчить про яскраво виражений адміністративний характер відповідних проваджень, оскільки здійснюються відповідні провадження органами виконавчої влади або органами місцевого самоврядування. Цієї ознаки цілком досить для висновку про те, що провадження зі зміни цільового призначення земельних ділянок відносяться до категорії адміністративних проваджень. Але визначення більш конкретного виду адміністративних проваджень потребує додаткової інформації.

Відповідно до частини третьої статті 20 ЗКУ, зміна цільового призначення земельних ділянок приватної власності здійснюється за ініціативою власників земельних ділянок. Ця обставина дає підстави стверджувати, що зміна цільового призначення земельної ділянки приватної власності може розглядатись як адміністративна послуга. 
Відповідно до п. 1 частини першої статті 1 Закону України «Про адміністративні послуги» [4] адміністративна послуга - результат здійснення владних повноважень суб'єктом надання адміністративних послуг за заявою фізичної або юридичної особи, спрямований на набуття, зміну чи припинення прав та / або обов'язків такої особи відповідно до закону. Але, хоча провадження щодо зміни цільового призначення земельної ділянки приватної власності здійснюється за заявою власника земельної ділянки, у такому провадженні не відбувається набуття, зміна або припинення прав чи обов'язків суб'єкта. Водночас відповідно до частини третьої статті 3 згаданого закону, до адміністративних послуг також прирівнюється надання органом виконавчої влади, іншим державним органом, органом влади Автономної Республіки Крим, органом місцевого самоврядування, їх посадовими особами, державним реєстратором, суб'єктом державної реєстрації витягів і виписок із реєстрів, довідок, копій, дублікатів документів та інші передбачені законом дії, у результаті яких суб'єкту звернення, а також об'єкту, що перебуває в його власності, володінні чи користуванні, надається або підтверджується певний юридичний статус і / або факт. У такому випадку ми маємо справу як раз із передбаченими законом діями, у результаті яких надається певний юридичний статус земельній ділянці. Тобто цільове призначення земельної ділянки, крім її розміру, координат тощо, $\epsilon$ елементом її правового статусу.

Іншими словами, провадження щодо зміни цільового призначення земельної ділянки приватної власності $€$ провадженням із надання адміністративних послуг не через відповідність ознакам, що містяться в легальному визначенні відповідного поняття, а через відповідність ознакам дій, прирівняних до адміністративних послуг.

Цікавим моментом у визначенні правової природи провадження щодо зміни цільового призначення земельної ділянки $\epsilon$ те, що дослідники адміністративних послуг у сфері земельних відносин не згадують цього провадження при побудові відповідних класифікацій. Так, Д.В. Бусу- йок пропонує за предметом земельні адміністративні послуги поділити на послуги щодо:

1) надання земельних ділянок державної та комунальної власності у власність або в користування;

2) передачі громадянам та юридичним осо6ам прав на земельні ділянки державної та комунальної власності;

3) проведення державної реєстрації прав на нерухоме майно, в тому числі прав на землю та їх о6тяжень;

4) проведення державної експертизи землевпорядної документації;

5) надання ліцензій на проведення ро6іт із землеустрою, землеоціночних ро6іт і земельних торгів;

6) проведення професійного відбору з питань створення фермерським господарств;

7) проведення агрохімічної паспортизації земель сільськогосподарського призначення;

8) видачі Кваліфікаційного свідоцтва оцінювача з експертної грошової оцінки земельних ділянок;

9) надання сільськогосподарських дорадчих послуг [5, с. 241].

Як бачимо, у наведеному переліку адміністративних послуг, пов'язаних зі зміною цільового призначення земельних ділянок, немає.

Хоча адміністративне провадження щодо зміни цільового призначення земельної ділянки приватної власності ми визнали як провадження з надання адміністративних послуг, за змістом правових наслідків надання відповідної адміністративної послуги його можна віднести до дозвільних адміністративних проваджень у сфері земельних відносин. Такий висновок можна зробити на підставі аналізу правових наслідків зміни цільового призначення земельної ділянки.

Відповідно до частини п'ятої статті 20 ЗКУ, види використання земельної ділянки в межах певної категорії земель визначаються ії̈ власником або користувачем самостійно в межах вимог, встановлених законом до використання земель цієї категорії, з урахуванням містобудівної документації та документації із землеустрою. Винятком із цього правила $\epsilon$ правовий режим земель сільськогосподарського призначення 
та земель оборони. Так, наприклад, зміна цільового призначення земельних ділянок зі складу земель рекреаційного призначення або оздоровчого призначення на земельні ділянки житлової чи громадської забудови, фактично означає дозвіл на здійснення відповідної будівельної діяльності на таких земельних ділянках, яка раніше не могла здійснюватися відповідно до правового режиму земель рекреаційного або оздоровчого призначення.

Із цього приводу можна звернутись до іншої класифікації, запропонованої Д.В. Бусуйок. Так, на її думку, за характером земельні адміністративні послуги можна поділити на реєстраційні, дозвільні и встановлення правового статусу [5, с. 241]. Зокрема, до дозвільних земельних адміністративних послуг Д.В. Бусуйок пропонує віднести послуги щодо: надання дозволів (надання дозволу на розроблення проєкту землеустрою щодо відведення земельної ділянки); видачі ліцензій на здійснення певних видів господарської діяльності (видача ліцензій на провадження землевпорядних і землеоціночних робіт). Своєю чергою у випадку надання земельних адміністративних послуг щодо встановлення правового статусу відбувається підтвердження наявності в конкретного суб'єкта достатнього досвіду роботи в певній сфері, необхідної кваліфікації.

На нашу думку, запропонована класифікація не зовсім коректна, оскільки провадження щодо зміни цільового призначення земельної ділянки приватної власності за цією класифікацією $€$ і дозвільним провадженням, і провадженням щодо встановлення правового статусу одночасно. Причому дозвільний його характер прямо випливає з встановлення відповідного правового статусу земельної ділянки, тобто дозвіл надається не як окреме рішення або документ, а випливає зі змісту зміненого правового статусу земельної ділянки.

Дещо іншу класифікацію адміністративних послуг пропонує Н.М. Козаченко. Так, вона виділяє земельні адміністративні (платні та безоплатні) послуги, земельні консультативно-дорадчі послуги, земельні проєктно-технічні послуги, земельні контрольно-правові послуги та земельні дозвільні послуги [6, с. 241]. У такій класифікації дозвільні послуги розглядаються окремо від адміністративних, хоча значна кількість адміністративних послуг за своїм змістом як раз і $\epsilon$ дозвільними або прямо, або опосередковано, як у випадку зі зміною цільового призначення земельних ділянок.

Структура провадження щодо зміни цільового призначення земельної ділянки приватної власності $€$ достатньо простою. Статтею 20 ЗКУ встановлено, що зміна цільового призначення земельних ділянок здійснюється за проєктами землеустрою щодо їх відведення. Такий проєкт розробляється на замовлення власника земельної ділянки без надання відповідного дозволу органами державної влади чи органами місцевого самоврядування в порядку, встановленому законом. Тобто, розроблення такого проєкту землеустрою здійснюється за межами відповідного адміністративного провадження, а само провадження щодо зміни цільового призначення починається з моменту подання проєкту землеустрою до відповідного органу для його затвердження та прийняття рішення про зміну цільового призначення земельної ділянки. Уповноважений суб'єкт владних повноважень у місячний строк із дня отримання проєкту землеустрою щодо відведення земельної ділянки приймає рішення про затвердження проєкту землеустрою щодо відведення земельної ділянки й зміну ії цільового призначення. Таке провадження здійснюється в стандартній для такого виду уповноважених органів порядку й не потребує стадії виконання рішення.

Як випливає 3 вищевикладеного, визначення правової природи провадження щодо зміни цільового призначення земельної ділянки не представляє особливої складності. Але провадження щодо зміни цільового призначення земельних ділянок державної або комунальної власності не може вважатись адміністративної послугою з огляду на те, що ініціатором відповідного провадження і його виконавцем $\epsilon$ одночасно один і той самий суб'єкт, а саме органи виконавчої влади або органи місцевого самоврядування, які приймають рішення про затвердження проєктів землеустрою щодо відведення земельних ділянок та передачу цих ділянок у власність або надання у користування. 
Отже, у такому випадку ми маємо справу зі звичайним адміністративним провадженням із прийняття управлінського рішення щодо зміни правового статусу земельної ділянки, а саме в частині її цільового призначення. Таке провадження здійснюється у формі, яка $€$ стандартною для адміністративних проваджень із прийняття владних рішень властивих суб'єктам владних повноважень певного виду, а саме органів виконавчої влади чи органів місцевого самоврядування.

На відміну від провадження щодо зміни цільового призначення земельних ділянок приватної власності, провадження щодо зміни цільового призначення земельних ділянок державної чи комунальної власності може мати складну структуру залежно від первинного правового статусу земельної ділянки.

Відповідно до частини шостої статті 20 ЗКУ, зміна цільового призначення особливо цінних земель допускається лише для розміщення на них об'єктів загальнодержавного значення, доріг, ліній електропередачі та зв'язку, трубопроводів, осушувальних і зрошувальних каналів, геодезичних пунктів, житла, об'єктів соціально-культурного призначення, об'єктів, пов'язаних 3 видобуванням корисних копалин, нафтових і газових свердловин та виробничих споруд, пов'язаних з їх експлуатацією, а також у разі відчуження земельних ділянок для суспільних потреб чи з мотивів суспільної необхідності, віднесення земель, зазначених у пунктах «a» і «б» частини першої статті 150 цього Кодексу, до земель природно-заповідного фонду та іншого природоохоронного призначення, земель історико-культурного призначення.

Якщо земельна ділянка відноситься до земель, які мають статус особливо цінних, то провадження щодо зміни ії̈ цільового призначення включає як необхідний елемент процедуру погодження. Так, наприклад, віднесення особливо цінних земель державної чи комунальної власності, визначених у пунктах «а» і «б» частини першої статті 150 ЗКУ, до земель інших категорій здійснюється за погодженням з Верховною Радою України. Погодження матеріалів місця розташування об'єкта, що передбачається розмістити на земельній ділянці особливо цінних земель державної чи комунальної власності зі зміною ії цільового призначення, здійснюється за погодженням 3 Верховною Радою України. Водночас порядок такого погодження визначено статтею 151 ЗКУ.

Слід зазначити, що в такому випадку має місце цікавий спосіб процесуального регулювання, який можна умовно назвати «регулювання за аналогією». У статті 151 ЗКУ визначено порядок погодження питань, пов'язаних з викупом земельних ділянок для суспільних потреб або з мотивів суспільної необхідності. Своєю чергою нормою частини шостої статті 20 ЗКУ такий порядок використовується і для погодження матеріалів місця розташування об'єкта, що передбачається розмістити на земельній ділянці особливо цінних земель державної чи комунальної власності зі зміною іiі цільового призначення. Така ситуація потребує певного уточнення змісту окремих стадій провадження та вимог до переліку документів, які подаються для погодження.

Крім того, відповідно до частини сьомої статті 20 ЗКУ, зміна цільового призначення земельних ділянок природно-заповідного й іншого природоохоронного призначення, історико-культурного, лісогосподарського призначення, що перебувають у державній чи комунальній власності, здійснюється за погодженням з Кабінетом Міністрів України.

Тобто у випадку із земельними ділянками приватної власності, провадження щодо зміни їх цільового призначення $\epsilon$ провадженням із надання адміністративних послуг. Результатом надання такої послуги є зміна правового статусу об'єкту, тобто земельної ділянки, що своєю чергою дозволяє власнику земельної ділянки здійснювати відносно цього об'єкта дії, обумовлені відповідним цільовим призначенням.

У випадку із земельними ділянками державної чи комунальної власності ми маємо справу з адміністративним провадженням щодо прийняття управлінського рішення суб'єкта владних повноважень в межах його правомочності володіння земельними ділянками державної чи комунальної власності. 
Висновки. Підсумовуючи викладене, можна стверджувати, що адміністративним провадженням щодо зміни цільового призначення земельних ділянок притаманний певний дуалізм правової природи. Залежно від форми власності зміна цільового призначення земельної ділянки може розглядатись або як провадження 3 надання адміністративних послуг, або як провадження з прийняття управлінського рішення в межах реалізації правомочностей управління земельними об'єктами державної чи комунальної власності.

\section{ЛITEРАТУРА:}

1. Земельний кодекс України : Закон України від 25 жовтня 2001 року № 2768-III / Верховна Рада України. Відомості Верховної Ради України. 2002. № 3-4. Ст. 27.

2. Ковальській Д.В. Земельно-процесуальні правовідносини : автореф. дис. ... канд. юрид. наук : 12.00.06. Харків, 2006. 20 с.

3. Світличний О.П. Адміністративні правовідносини у сфері земельних ресурсів України: проблеми теорії та практики правозастосування : монографія. Донецьк : Державне вид-во «Донбас», 2011. 410 с.

4. Про адміністративні послуги : Закон України від 6 вересня 2012 року № 5203-VI / Верховна Рада України. Відомості Верховної Ради України. 2013. № 32. Ст.409.

5. Бусуйок Д.В. Класифікація земельних адміністративних послуг. Часопис Київського університету права. 2011. № 1. С. 239-245.

6. Козаченко Н.М. Система надання публічних послуг у сфері земельних відносин в Україні: становлення та трансформації. Державне управління та місцеве самоврядування. 2012. Вип. 4 (15). С. 236-243. 